\title{
Our Unconstitutional Reapportionment Process
}

\author{
Gerard N. Magliocca*
}

\begin{abstract}
This Essay argues that the process used to reapportion representatives among the states after each census violates Section Two of the Fourteenth Amendment. Section Two provides that the apportionment of representatives must be done based on total population unless a state disenfranchises a sufficient number of people who are defined as presumptively eligible voters, in which case that state's number of representatives must be reduced. The reapportionment statutes instead say that apportionment must be done based solely on population. By erasing Section Two's penalty provision, these statutes are unconstitutional. There is still time for Congress to correct this defect before the next census. If that is not done, though, then the federal courts can and should declare the next reapportionment null and void.
\end{abstract}

\section{TABle of CONTENTS}

InTRODUCTION ................................... 775

I. Distributing Representatives Among the States. 778

A. The Era of Sunsets $(1790 s-1910 s) \ldots \ldots \ldots \ldots \ldots . . . \ldots 779$

B. The Reapportionment Act of 1929 .............. 780

II. Section Two of the Fourteenth Amendment...... 783

A. The Background and Text of Section Two ........ 783

B. The First Application of Section Two-The 1872 Reapportionment .......................... 786

C. Section Two and the Reapportionment Act of 1929 . 790

III. The Second Reconstruction .................... 792

A. Section Two and the Civil Rights Act of 1964 ...... 792

B. Lampkin v. Connor .......................... 794

IV. Possible Responses to a Section Two Claim ....... 797

A. Is There a Saving Construction? ................ 797

B. Justiciability and Standing.................... 800

C. Is This Pointless Formalism?.................. 802

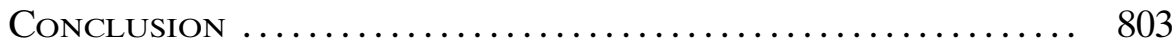

* Samuel R. Rosen Professor, Indiana University Robert H. McKinney School of Law. My thanks to Will Baude, Brian Kalt, Mike Pitts, and Amanda Tyler for their comments on prior drafts.

May 2018 Vol. 86 No. 3 
Representatives shall be apportioned among the several States according to their respective numbers, counting the whole number of persons in each State, excluding Indians not taxed. But when the right to vote at any election for the choice of electors for President and Vice President of the United States, Representatives in Congress, the Executive and Judicial officers of a State, or the members of the Legislature thereof, is denied to any of the male inhabitants of such State, being twenty-one years of age, and citizens of the United States, or in any way abridged, except for participation in rebellion, or other crime, the basis of representation therein shall be reduced in the proportion which the number of such male citizens shall bear to the whole number of male citizens twentyone years of age in such State.

- Section Two of the Fourteenth Amendment ${ }^{1}$

\section{INTRODUCTION}

Determining how many members each state is entitled to in the House of Representatives is among the most routine constitutional tasks. ${ }^{2}$ Every ten years, a census is conducted under the auspices of the Commerce Department. ${ }^{3}$ The Department plugs the state and national population data from the census into a mathematical formula codified by Congress in 1941 that yields the total number of representatives for each state. ${ }^{4}$ These tallies are then certified by the President and become final without any legislative action. ${ }^{5}$

This Essay contends that the current reapportionment process violates Section Two of the Fourteenth Amendment. Section Two states, in part, that if the right to vote in federal and most state elections is

1 U.S. Const. amend. XIV, § 2.

2 See, e.g., Franklin v. Massachusetts, 505 U.S. 788, 792 (1992) (summarizing this automatic process).

3 See U.S. Const. art I., § 2, cl. 3 ("The actual Enumeration shall be made within three Years after the first Meeting of the Congress of the United States, and within every subsequent Term of ten Years, in such Manner as they shall by Law direct.”); 13 U.S.C. § 2 (2012) (stating that the Census Bureau is under the jurisdiction of the Commerce Department); id. $\S 141$ (a) (2012) (stating that the Secretary of Commerce is responsible for taking the census). Other agencies, such as the Interior Department, were responsible for overseeing the census in the past. See infra note 7 .

4 See 13 U.S.C. $\$ 141$ (a)-(b); see also 2 U.S.C. § 2(b) (2012) (stating the reapportionment formula in general terms); U.S. Dep't of Commerce v. Montana, 503 U.S. 442, 451-55 (1992) (describing the formula and the leading alternatives considered by Congress).

5 See 2 U.S.C. $\$ 2$ (a) (2012); cf. Charles W. Eagles, Democracy Delayed: CongresSional ReApportionment and Urban-Rural Conflict in the 1920s 32-84 (1990) (discussing the legislative stalemate after the 1920 Census that led to the creation of the present system). 
denied or in any way abridged by a state for a broad class of presumptively eligible voters, then that state's delegation in the House of Representatives shall be reduced in proportion to the degree of disenfranchisement. ${ }^{6}$ Consistent with this constitutional command, the first census taken after the Fourteenth Amendment's ratification tried to count how many people fell within Section Two's language on imposing a representation penalty. ${ }^{7}$ The results were sent to Congress and discussed in the debates that culminated in the first post-Reconstruction reapportionment statute. ${ }^{8}$ Today, by contrast, the Commerce Department is barred from considering Section Two of the Fourteenth Amendment in assessing how many representatives each state should receive. ${ }^{9}$ Section Two cannot be considered because the modern reapportionment statutes do not include a variable that permits consideration of that provision-only population figures may be used. ${ }^{10}$

It is axiomatic that a federal statute cannot override a constitutional command, ${ }^{11}$ but that is precisely what the reapportionment statutes do by omitting any reference to Section Two of the Fourteenth Amendment. Current state voting regulations may not require the imposition of a Section Two penalty, but Congress cannot say-as current law does-that no penalty may ever be imposed pursuant to the authority delegated to the executive branch. Put another way, Section

6 See U.S. Const. amend. XIV, § 2. Section Two defines those presumptive voters in part as "male inhabitants of such State, being twenty-one years of age," id., but this text must be read in light of subsequent constitutional amendments that bar the states from generally denying the right to vote to women or people older than eighteen, see id. amends. XIX, XXVI; infra text accompanying notes 89-92. Congress has discretion to say what denied or "in any way abridged" means, but one exception involves people barred from voting due to a felony conviction. See Richardson v. Ramirez, 418 U.S. 24, 54 (1974). Section Two expressly excludes people disenfranchised "for participation in rebellion, or other crime," which the Supreme Court held applies to felons or ex-felons. See id. at 43,54 .

7 See Census Office, Dep't of the Interior, Instructions to Assistant Marshals 11-12 (1870); see also Cong. Globe, 42d Cong., 2d Sess. 83 (1871) (setting forth the suffrage data that was collected).

8 See, e.g., George David Zuckerman, A Consideration of the History and Present Status of Section 2 of the Fourteenth Amendment, 30 Fordham L. Rev. 93, 110-14 (1961) (summarizing the debate and Congress's conclusion that no Section Two penalty was warranted in 1871).

9 See infra Section I.B. Part IV assesses if, in the name of avoiding constitutional difficulties, the reapportionment statutes can be read as giving the Commerce Department discretion to consider Section Two. Compare Michael Hurta, Note, Counting the Right to Vote in the Next Census: Reviving Section Two of the Fourteenth Amendment, 94 TEx. L. REv. 147, 166-69 (2015) (contending that these laws can be construed as delegating Congress's Section Two authority), with infra Section IV.A (rejecting this construction).

10 Knowledge of the specific calculations used to allocate representatives is not required to understand the constitutional analysis in this Essay, though the formula is reproduced within. See infra note 42.

11 See, e.g., Marbury v. Madison, 5 U.S. (1 Cranch) 137, 176-77 (1803). 
Two says that there is an exception to using total population figures to reapportion representatives under certain conditions, but the reapportionment statute says there is no such exception.

The claim that the reapportionment process used since World War II is unconstitutional may seem extraordinary, but the same point was made during the civil rights era. In the early 1960s, Congress's failure to enforce Section Two of the Fourteenth Amendment against the flagrant exclusion of African-Americans from the ballot box received fresh attention. ${ }^{12}$ Indeed, there was a specific written demand in the program for the 1963 March on Washington for Jobs and Freedom led by Martin Luther King, Jr. for the "[e]nforcement of the Fourteenth Amendment-reducing Congressional representation of states where citizens are disfranchised." 13 As part of this brief renaissance, a few scholars observed that the reapportionment laws violated Section Two by ignoring its penalty clause. ${ }^{14}$ More important, the NAACP Legal Defense Fund filed litigation seeking a declaratory judgment that would have invalidated the reapportionment formula on that basis. ${ }^{15}$ After the Voting Rights Act became law in 1965, however, academic interest in Section Two waned. ${ }^{16}$ Likewise, the

12 See, e.g., Ben Margolis, Judicial Enforcement of Section 2 of the Fourteenth Amendment, 23 Law Transition 128 (1963); Zuckerman, supra note 8; $c f .3$ Bruce Ackerman, We the People: The Civil Rights Revolution 331 (2014) (discussing Section Two and stating that "[i]t is true, of course, that neither Congress nor the Court enforced this constitutional requirement during the first two-thirds of the twentieth century, allowing the white South to retain its full share of House members despite blatant acts of black disenfranchisement").

13 March on Washington for Jobs and Freedom: Lincoln Memorial Program 4 (1963), http://www.crmvet.org/docs/mowprog.pdf. In the past, "disfranchisement" was used instead of "disenfranchisement" to describe voting barriers. The latter term is now more common, and thus this Essay will use disenfranchisement unless quoting an older source that says otherwise.

14 See Eugene Sidney Bayer, The Apportionment Section of the Fourteenth Amendment: A Neglected Weapon for Defense of the Voting Rights of Southern Negroes, 16 W. RES. L. REV. 965, 990 (1965) (stating that "because no account is taken of the provisions of section 2" in the reapportionment laws, "any apportionment based on such figures would be unconstitutional"); Arthur Earl Bonfield, The Right to Vote and Judicial Enforcement of Section Two of the Fourteenth Amendment, 46 CoRnell L.Q. 108, 122 (1960) ("[The reapportionment statute] is clearly unconstitutional as being in conflict with section 2 of the fourteenth amendment. It contemplates and perpetuates an apportionment based solely on population, no account being taken of those disfranchised in each state.”).

15 See Lampkin v. Connor, 360 F.2d 505, 507 (D.C. Cir. 1966); NAACP Challenges Seats of 21 Southern Congressman: Claims They Violate Fourteenth by Not Serving All Voters, PitT. CouRIER, Nov. 28, 1964, at 5 [hereinafter NAACP Challenges].

16 Voting Rights Act of 1965, Pub. L. No. 89-110, 79 Stat. 437. The best recent article on the original understanding of Section Two is Earl M. Maltz, The Forgotten Provision of the Fourteenth Amendment: Section 2 and the Evolution of American Democracy, 76 LA. L. REv. 149 (2015). 
NAACP's reapportionment lawsuit was dismissed on prudential grounds by the D.C. Circuit pending an "appraisal of the effectiveness of the new Voting Rights Act" and was never refiled. ${ }^{17}$

After more than a century of neglect, it is time to treat Section Two of the Fourteenth Amendment with the respect due to a constitutional provision. Congress must revise the reapportionment statutes to let the executive branch or an institution within the legislative branch consider Section Two. ${ }^{18}$ If Congress fails to act, then a state with standing to challenge the next round of reapportionment results should raise a Section Two claim, and the Supreme Court should respond by holding that the present allocation system is unconstitutional.

Part I explores the history of congressional reapportionment and describes the contemporary process. Part II discusses Section Two of the Fourteenth Amendment and how that provision was applied by Congress in the reapportionments conducted before the modern statute was enacted in 1929. Part III addresses the rediscovery of Section Two in the 1960s and the constitutional concerns raised at that time about reapportionment. Part IV concludes by explaining why the current statute is irreconcilable with Section Two and why a judicial declaration to that effect is proper.

\section{Distributing Representatives Among the States}

This Part provides essential background on how the House of Representatives is reapportioned following each census. From the 1790s until the 1910s, Congress took the census information and then cobbled together a statute determining how many total representatives there would be and how many each state would get. Following the 1920 Census, though, Congress could not agree on a new reapportionment, and as a result, one was not done during that decade. ${ }^{19}$ To break that deadlock, Congress enacted the Reapportionment Act of

17 See Lampkin, 360 F.2d at 511.

18 This Essay takes no position on the substantive standard that should be used to assess denials or abridgements of voting rights pursuant to Section Two. The standard could be set forth by Congress in a legislative revision or that task could be delegated to the Commerce Department. Likewise, the Essay is agnostic on whether Congress should impose a duty on the Commerce Department to make such an assessment.

19 See EAgles, supra note 5, at 21-31. Some scholars at the time raised the prospect that this failure could lead to constitutional challenges against the results of congressional or presidential elections, though this never occurred. See Zechariah Chafee, Jr., Congressional Reapportionment, 42 HARv. L. REv. 1015, 1015-17 (1929). 
$1929,{ }^{20}$ which provided that (1) henceforth the total number of representatives would be maintained at 435 , (2) a formula would be used to redistribute them based solely on population, and (3) Congress would no longer need to legislate for reapportionments to occur. This automatic system is still in operation. ${ }^{21}$

\section{A. The Era of Sunsets (1790s-1910s)}

Until the 1920s, Congress actively participated in reapportionment, and each reapportionment effectively sunsetted after ten years. When the Framers assigned the initial 65 representatives to the 13 states in the Constitution, they did so without reliable state or national population figures. $^{22}$ To rectify that problem, Article One, Section Two provided that an "actual Enumeration shall be made within three Years after the first Meeting of the Congress of the United States."23 With that data in hand and two new states in the Union, Congress enacted a statute in 1792 that increased the total number of representatives to 105 and redistributed them among the fifteen states. ${ }^{24}$

The most perplexing issue that arose in the initial reapportionment debate was how fractional representatives should be allocated. No matter what overall number of members is chosen, dividing the national and state populations by that figure will not yield a whole number for each state. For instance, when people say that a state is entitled to thirteen representatives, what they really mean is that the state should receive 12.7 or 13.2 members. There are many ways of distributing these fractions, but each one slightly favors a different group of states or could favor one political party. In the first reapportionment law, Congress adopted Thomas Jefferson's view that fractions should be disregarded, which gave an edge to larger states. ${ }^{25}$

20 Reapportionment Act of 1929, ch. 28, § 22, 46 Stat. 21, 26-27 (codified as amended at 2 U.S.C. § $2 \mathrm{a}(2012))$.

21 The House of Representatives was temporarily enlarged to 437 members after the admission of Alaska and Hawaii to the Union, but the total reverted to 435 after the 1960 reapportionment. See Jeffrey W. Ladewig, One Person, One Vote, 435 Seats: Interstate Malapportionment and Constitutional Requirements, 43 Conn. L. Rev. 1125, 1147-48 (2011).

22 See U.S. Const. art. I, § 2, cl. 3 (listing each state and the associated number of representatives); $c f$. Akhil Reed Amar, America's Constitution 86 (2005) (stating that the initial distribution was "an avowedly temporary allotment that plainly sprang from guesswork and horse-trading”).

23 U.S. Const. art. I, § 2, cl. 3.

24 See U.S. Dep't of Commerce v. Montana, 503 U.S. 442, 448-50 (1992); EAgLEs, supra note 5 , at $23-25$.

25 Montana, 503 U.S. at 449-50 (stating that this is sometimes called the "method of greatest divisors"); EAGLEs, supra note 5, at 25. Another way of describing this approach is rounding down. 
The 1792 statute was the template for the next dozen reapportionments and was the backdrop against which Section Two of the Fourteenth Amendment was ratified. After each census, Congress looked at the results and took up the reapportionment issue anew, changing the number of representatives, the average ratio of people per representative, and the method used to allocate fractions. ${ }^{26}$ In all of these reapportionments, the overall person-to-member ratio stayed the same or grew, and in all but one of them the total number of House members increased. ${ }^{27}$ The method used to distribute the fractions, though, was more unstable. In 1842, Congress abandoned Jefferson's view and went with Daniel Webster's idea that states with fractions greater than one-half should receive an extra member. ${ }^{28}$ Ten years later, Congress switched to Alexander Hamilton's suggestion that the states with the largest fractions should receive an additional seat until none were left to allocate. ${ }^{29}$ In 1911, however, Congress went back to Webster's rounding-up solution. ${ }^{30}$

\section{B. The Reapportionment Act of 1929}

During the 1920s, the consensus on reapportionment broke down as Congress was unable to agree on a new statute. Many factors contributed to this stalemate (including Section Two of the Fourteenth Amendment), ${ }^{31}$ but the result was that the elections for the House and for the White House that were held in that decade used the same distribution of representatives and electoral votes used in the 1910s. ${ }^{32}$ By 1929, public outrage at the House's malapportionment led President Herbert Hoover to demand action from Congress. ${ }^{33}$ In response, a

26 Montana, 503 U.S. at 450-51; EAGLEs, supra note 5, at 25-31.

27 See EAgles, supra note 5, at 25-26. The exception was the 1842 reapportionment, which reduced the size of the House of Representatives from 240 to 223. See id. at 26.

28 See Montana, 503 U.S. at 450-51 (calling this the "method of major fractions"). One way of describing this approach is rounding up.

29 See id. at 449, 451 \& n.22; EAGLEs, supra note 5, at 24.

30 See Montana, 503 U.S. at 451.

31 The best overview of this reapportionment debate is EAGLES, supra note 5, at 32-84. Some of the sticking points were (1) the question of whether the size of the House should increase beyond 435 members; (2) the argument by members from rural districts that the census population results were skewed in favor of cities by the temporary internal migration caused by World War One; and (3) the divisions over the formula that should be used to allocate representatives. $I d$. The role played by Section Two of the Fourteenth Amendment is discussed in Part II. See infra text accompanying notes 84-89.

32 The number of electoral votes for each state is partly determined by their total representative count. See U.S. ConsT. art II, § 1, cl. 2.

33 See Herbert Hoover, Message to the Special Session of the Congress on Farm Relief, Tariff, and Certain Emergency Legislation (1929), reprinted in The Pub- 
compromise was struck - the Reapportionment Act-that delegated Congress's reapportionment authority to the President under strict guidelines that still apply. ${ }^{34}$

The main elements of this compromise were that (1) the overall size of the House would not change; (2) the average number of constituents per representative would increase organically as the population swelled; and (3) the formula used to redistribute representatives among the states would not permit any administrative discretion once the census was done. There were two advantages to these reforms..$^{35}$ First, the reapportionment process was removed from partisan politics. ${ }^{36}$ Prior to 1929 , if one party controlled Congress and the Presidency when the census was complete, that temporary advantage could be leveraged into a decade-long edge by manipulating the size and distribution of the House of Representatives. ${ }^{37}$ Although Congress retains the right to legislate in this biased manner, that kind of power grab is harder to make once reapportionment is understood as a routine bureaucratic task. Second, the delegation of reapportionment under an automatic formula eliminated the possibility that the logjam of the 1920s could occur again and leave the House malapportioned. ${ }^{38}$

To resolve the debate about how fractions should be allocated, the National Academy of Sciences issued a report recommending that a new equation - the method of equal proportions-be used. ${ }^{39}$ Congress agreed and used the method of equal proportions for the 1931

lic Papers of the Presidents of the United States: Herbert Hoover, 1929, at 75, 80-81 (1974).

34 See Byron J. Harden, House of the Rising Population: The Case for Eliminating the 435Member Limit on the U.S. House of Representatives, 51 WASHBURn L.J. 73, 81 (2011).

35 One disadvantage of the Reapportionment Act is that the membership of the House of Representatives may now be too small (or put another way, each member may now represent too many people). For a persuasive statement of that position, see generally $i d$.

36 See U.S. Dep't of Commerce v. Montana, 503 U.S. 442, 465 (1992) ("[I]f a set formula is otherwise constitutional, it seems to us that the use of a procedure that is administered efficiently and that avoids partisan controversy supports the legitimacy of congressional action, rather than undermining it.").

37 At the state level, of course, this sort of partisan gamesmanship still occurs with respect to congressional redistricting.

38 On the other hand, the pre-1920 practice did force Congress to reexamine every ten years how House elections were conducted, which occasionally led to reforms such as the abolition of at-large elections in states with more than one representative, see Act of June 25, 1842, ch. $47, \S 2,5$ Stat. 491 , and the requirement for a period of time that each congressional district have "as nearly as practicable an equal number of inhabitants," Act of Feb. 2, 1872, ch. 11, § 2, 17 Stat. 28. For an insightful analysis of these statutes, see Pamela S. Karlan, Reapportionment, Nonapportionment, and Recovering Some Lost History of One-Person, One Vote, 59 Wм. \& MARy L. Rev. 1921, 1928-34 (2018).

39 See Montana, 503 U.S. at 452-56. 
reapportionment, though the standard was not codified until $1941 .{ }^{40}$ The 1941 law provided that in the first session of each Congress after a census
the President shall transmit to the Congress a statement showing the whole number of persons in each State, exclud- ing Indians not taxed, as ascertained under the seventeenth and each subsequent decennial census of the population, and the number of Representatives to which each State would be entitled under an apportionment of the then existing number of Representatives by the method known as the method of equal proportions, no State to receive less than one Member. ${ }^{41}$

A precise description of the method of equal proportions is included in the footnote below. ${ }^{42}$

40 See id. at 451-52; see also 2 U.S.C. $\S 2$ a (2012) (codifying the method of equal proportions).

$41 \quad I d . \S 2 \mathrm{a}(\mathrm{a})$. The Constitution mandates that each state receive at least one member in the House of Representatives. See U.S. Const. art. I, § 2, cl. 3.

42 The method of equal proportions is described on the Census Bureau website as follows:

\section{Equal Proportions Method}

$P$ - represents a state's total population

$\mathrm{n}$ - represents the number of seats a state would have if it gained a seat (because all states automatically received one seat the next seat gained is "seat two," and the next "seat three," and the next "seat four," and so on).

The multiplier equals:

$$
1 / \sqrt{n(n-1)}
$$

[which is called the reciprocal of the geometric mean]. Computing these values is quite easy using a PC and a good spreadsheet package.

Thus the formula for calculating the multiplier for the second seat is:

$$
1 / \sqrt{2(2-1)}
$$

or $1 / 1.414213562$ or 0.70710678

The multiplier for the third seat is:

$$
1 / \sqrt{3(3-1)}
$$

$1 / 2.449489743$ or 0.40824829

....

Continue until an appropriate number of multipliers have been calculated.

Once the "multipliers" have been calculated, the next step is to multiply this figure by the population total for each of the 50 states (the District of Columbia is not included in these calculations). The resulting numbers are the priority values. Make sure you compute enough multipliers to cover the largest [number] of seats in the U.S. House of Representatives that any one state stands to gain. Multipliers and priority values must be calculated for the largest number of seats assigned to a state. For example, if the largest number of seats assigned to a state is 50 , multipliers and priority values must be calculated for the 50th seat. . .

Once you've calculated priority values for each state for the total anticipated seats, the next step is to rank and number the resulting priority values starting with seat 
The crucial takeaway is that the equation does not permit the Commerce Department, which is currently charged with implementing congressional reapportionment, to consider how Section Two of the Fourteenth Amendment might affect the results. This presents a significant constitutional issue because Section Two speaks directly to how many representatives each state should receive in a reapportionment. To understand that point, though, a tutorial on Section Two is necessary.

\section{Section Two of the Fourteenth Amendment}

This Part describes Section Two of the Fourteenth Amendment and its application to the reapportionment process until the 1920s. Section Two says that if a state denies or in any way abridges the voting rights for men over the age of twenty-one in federal and most state elections, then that state shall lose some of its members in the House of Representatives. ${ }^{43}$ The one thing that most scholars know about Section Two is that its penalty clause has never been enforced. ${ }^{44}$ In the first reapportionment conducted after the Fourteenth Amendment's ratification, though, the census and Congress carefully assessed if Section Two should be enforced. ${ }^{45}$ More important, Section Two's abysmal record of enforcement does not mean that Congress can prohibit enforcement as the reapportionment statutes do.

\section{A. The Background and Text of Section Two}

When the Thirty-Ninth Congress convened in December 1865, one of the most pressing issues involved the voting rights of freed

51 until all 435 seats have been assigned (remember, each state automatically received one seat). Next, tally the number of seats for each state to arrive at the total number of seats in the House of Representatives apportioned to each state.

Congressional Apportionment: Computing Apportionment, U.S. Census Bureau (Feb. 4, 2013), https://www.census.gov/population/apportionment/about/computing.html.

43 See U.S. Const. amend. XIV, § 2.

44 See, e.g., Franita Tolson, What Is Abridgment?: A Critique of Two Section Twos, 67 AlA. L. REv. 433, 434 (2015).

45 This fact undercuts the argument that the Fifteenth Amendment implicitly repealed the penalty clause in Section Two of the Fourteenth Amendment. See Gabriel J. Chin, Reconstruction, Felon Disenfranchisement, and the Right to Vote: Did the Fifteenth Amendment Repeal Section 2 of the Fourteenth Amendment?, 92 Geo. L.J. 259, 263 (2004). The Fifteenth Amendment was ratified in 1870, but the debate over the 1871 reapportionment treated Section Two as valid. See infra text accompanying notes 72-78. Moreover, the text of Section Two's penalty clause can be applied to almost any suffrage limit, whereas the Fifteenth Amendment only talks about voting limits based on "race, color, or previous condition of servitude." See U.S. Const. amend. $\mathrm{XV}, \S 1$. Finally, the Supreme Court has never said that the Section Two penalty provision was implicitly repealed. 
slaves. Prior to the Thirteenth Amendment's ratification, slaves counted as three-fifths of a person for purposes of representation and reapportionment but could not vote. ${ }^{46}$ With the end of slavery, the exConfederate States were entitled to additional members in the House of Representatives because their ex-slaves would now be counted as whole persons. ${ }^{47}$ Guaranteeing suffrage for the former slaves would justify that bonus by ensuring that the extra House members from the states would represent actual voters from both races. The challenge was that there was insufficient political support in 1866 for a constitutional amendment barring states from imposing racial discrimination in voting. ${ }^{48}$

Consequently, Congress tried to craft a rule that merely discouraged states from excluding freed slaves from voting, but this idea foundered on the difficulty of defining the pool of eligible voters. The Joint Committee on Reconstruction initially proposed that when the "elective franchise shall be denied or abridged in any State on account of race or color, all persons of such race or color shall be excluded from the basis of representation." ${ }^{49}$ A problem with this draft was that every state then barred African-American women from voting, and thus the proposed language would give states an incentive to enfranchise some, but not all, women. ${ }^{50}$ Congress eventually resolved this dilemma (and acknowledged the almost complete absence of women's suffrage in the states at the time) by defining the relevant class as men and adding, for the first time, the word "male" into the Constitution. ${ }^{51}$ Subsequent debate led to other clarifications that male chil-

46 See U.S. Const. art. I, § 2, cl. 3.

47 See, e.g., Gerard N. Magliocca, American Founding Son: John Bingham and the Invention of the Fourteenth Amendment 112-13 (2013).

48 See Maltz, supra note 16, at 154-55, 162-67. When John Bingham, the drafter of the Equal Protection Clause, was asked in January 1866 whether he supported voting rights for African-American men, he told the House, "I will answer with all my heart that I am ready to go for that. But a majority of those with whom I am associated think that [Section Two] is all that is needed at present . . . ." Cong. Globe, 39th Cong., 1st Sess. 431 (1866) (statement of Rep. Bingham); see also id. at 432 ("The reason why I support the proposed amendment is that I believe it essential and attainable. I do not dare to say that it could not be improved.").

49 Maltz, supra note 16, at 155; see also Zuckerman, supra note 8, at 96 (providing some additional background).

50 In other words, a state with a significant population of African-American women could lose representatives by refusing to extend suffrage rights to those women, but the state would suffer no such loss for declining to enfranchise white women.

51 See AmAr, supra note 22, at 393-94. Congressman Thaddeus Stevens observed at one point that he did "not think we ought to disfigure the Constitution" by inserting the word "male" into the Fourteenth Amendment, Cong. Globe, 39th Cong., 1st Sess. 537 (1866) (statement of Rep. Stevens), but he ultimately acquiesced in doing just that because there was no viable alternative. 
dren (who could not vote in any state) and male aliens (who could vote in only some) were also not included in the voting base. ${ }^{52} \mathrm{~A}$ lastminute revision in the Senate also resulted in language that designated the specific elections that were covered. ${ }^{53}$

The final text of Section Two made clear that the penalty clause was tightly linked to reapportionment and the census. ${ }^{54}$ Section Two begins by repeating Article One's language on how representatives must be allocated (without the Three-Fifths Clause): "Representatives shall be apportioned among the several States according to their respective numbers, counting the whole number of persons in each State, excluding Indians not taxed." 55 The exception to this reapportionment method occurs "when the right to vote at any election for the choice of electors for President and Vice President of the United States, Representatives in Congress, the Executive and Judicial Officers of a State, or the members of the Legislature thereof, is denied to any of the male inhabitants of such State, being twenty-one years of age and citizens of the United States, or in any way abridged, except for participation in rebellion, or other crime." 56

If these conditions are met, then "the basis of representation therein shall be reduced in the proportion which the number of such male citizens shall bear to the whole number of male citizens twentyone years of age in such State." 57 The use of the word "shall" in this

52 See Jamin B. Raskin, Legal Aliens, Local Citizens: The Historical, Constitutional, and Theoretical Meanings of Alien Suffrage, 141 U. PA. L. REv. 1391, 1414, 1429 (1993) (discussing past alien suffrage and modern children's suffrage). States that did not permit alien suffrage, of course, stood to lose representatives if aliens were included in the presumptive voting base and were able to insist on a citizenship requirement in the drafting process.

53 See Maltz, supra note 16, at 171, 176-77. The concern here was that some local elections should be restricted to property owners and thus excluded from Section Two. See Zuckerman, supra note 8 , at 106 .

54 See, e.g., Cong. Globe, 39th Cong., 1st Sess. 3038 (1866) (statement of Sen. Howard) ("The census-taker will find it necessary, whenever he makes the count of the inhabitants of the particular State or district when he is acting, to ascertain, as precisely as he is able, and to note down in his tables the various persons within the State who are capacitated to vote for any one or all of these five classes of public officers [listed in Section Two].”).

55 U.S. Const. amend. XIV, § 2.

56 Id. Two tangential observations about Section Two are appropriate here. First, this is the only constitutional provision that explicitly recognizes the validity of state judicial elections, a practice that was well established by the 1860s and continues today. See generally Jed HANDELSman Shugerman, The People's Courts: Pursuing Judicial Independence in America 105 (2012) (offering a comprehensive review of state judicial elections). Second, Section Two's exception for "participation in rebellion" was included to permit the disenfranchisement of exConfederates in the South without any penalty. See Maltz, supra note 16, at 171.

57 U.S. Const. amend. XIV, § 2. In 1892, the Supreme Court described Section Two in dicta as protecting "the right to vote as established by the laws and constitution of the State." 
final part establishes that Section Two imposes a mandate if the relevant facts on voting rights defined by the first part are present.

\section{B. The First Application of Section Two-The 1872 Reapportionment}

The initial decisions on Section Two after the Fourteenth Amendment was ratified confirm the original understanding that the application of the penalty clause was part of the reapportionment process. A House Select Committee was appointed, led by James A. Garfield (the future President), to study how the 1870 Census should be undertaken consistent with the new constitutional rule. ${ }^{58}$ In its report, the Committee explained, "The thirteenth and fourteenth amendments of the national Constitution have radically changed the basis of representation and provided for a redistribution of political power." 59 "The census," the report added, "is our only constitutional means of determining the political or representative population."60 Since Section Two "excludes all who are denied the ballot on any and all grounds other than the two specified," i.e., participation in rebellion, or other crime, the Committee recommended that the next census just ask every adult man if his "right to vote is denied or abridged on other grounds than rebellion or crime." ${ }_{11}$ Congressman Garfield conceded "that this will allow the citizen to be a judge of the law as well as the fact, and that it will be difficult to get true and accurate answers," but argued that there was no better method. ${ }^{62}$

While the Select Committee did not provide a substantive standard to the census-takers charged with gathering suffrage data, the Garfield Report did provide a detailed analysis of state voting restrictions that fell within the scope of Section Two. The Report stated that when the Fourteenth Amendment was ratified, "it was generally understood that the exclusion applied only to colored people who should

McPherson v. Blacker, 146 U.S. 1, 39 (1982). Taken literally, this would mean that a state could redefine the presumptively eligible voter pool, which cannot be right. What the Court probably meant was that some state limitations on the right to vote for adult male citizens should not be construed as "denying" or "in any way abridging" the right to vote for purposes of the penalty clause.

58 See H.R. Rep. No. 41-3, at 1, 52 (1870) [hereinafter Ninth Census Report]; Zuckerman, supra note 8 , at 108 . The House Census Report also discussed a wide range of subjects beyond Section Two. See Ninth Census Report, supra.

59 Ninth Census Report, supra note 58, at 52.

60 Id.

61 Id. at $52-53$.

$62 \mathrm{Id}$. at 53. 
be denied the ballot by the laws of their State." ${ }^{63}$ Nevertheless, this narrow construction could not be squared with the broad language of the penalty clause. ${ }^{64}$ As a result, the Report listed every voting requirement or restriction in every state, ${ }^{65}$ and these were classified into nine groups: (1) race or color; (2) residency; (3) property ownership; (4) literacy; (5) character; (6) active military service; (7) "pauperism, idiocy, and insanity"; (8) refusal to take a required oath; and (9) other. ${ }^{66}$ Some of these restrictions were categorical, while others involved the exercise of discretion by state officials (for example, giving a literacy test or, in some instances, assessing the character of a voter).

The Interior Department, which ran the census in that era, adopted the House Committee's idea of simply asking adult men if their right to vote was denied or abridged. ${ }^{67}$ One new question in the 1870 Census asked if someone was a male American citizen age twenty-one or older. If so, the next question asked whether his right to vote was denied on grounds other than rebellion or crime. ${ }^{68}$ In explaining these changes to the Assistant Marshals who were charged with gathering this information, the Interior Secretary said, "Upon the answers to the questions under this head will depend the distribution of representative power in the General Government. It is therefore imperative that this part of the enumeration should be performed with absolute accuracy."69 While counting the number of adult male citizens was easy, "it is a matter of more delicacy to obtain the [voting rights] information":

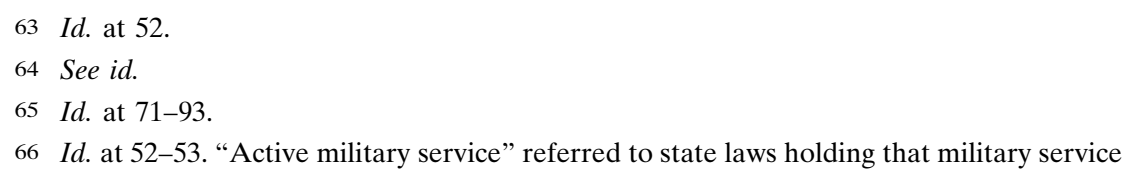
within the state did not create residency sufficient for voting.

67 No legislation was enacted to authorize or direct the Interior Department to ask census questions about Section Two. See Zuckerman, supra note 8, at 109-10. One way of understanding the Department's decision to ask those questions is that the Fourteenth Amendment imposes a duty to do so. If that is true, then every census after 1870 was unconstitutional because Section Two questions were not asked. I do not think, though, that this is the only way of justifying the Department's decision to add the questions in 1870. Nothing in the existing statutes precluded the census from asking new questions, and so one could say that the Department exercised its discretion to examine Section Two. For a discussion of this issue, see Cong. Globe, 42d Cong., 2d Sess. 82-83 (1871) (statement of Rep. Garfield).

68 Notably, the census question did not use the term "in any way abridged" and did not mention the offices listed in Section Two. For a reproduction of the 1870 Census Form, see Nat'l Archives \& Recs. Admin., Form NA 14085 (04-09): 1870 Federal Census, https:// www.archives.gov/files/research/genealogy/charts-forms/1870-census.pdf.

69 Census Office, Dep't of the Interior, supra note 7, at 11. 
Many persons never try to vote, and therefore do not know whether their right to vote is or is not abridged. It is not only those whose votes have actually been challenged, and refused at the polls for some disability or want of qualification, who must be reported in this column; but all who come within the scope of any State law denying or abridging suffrage to any class or individual on any other ground that participation in rebellion, or legal conviction of crime. Assistant Marshals, therefore, will be required carefully to study the laws of their own States in these respects, and to satisfy themselves, in the case of each male citizen of the United States above the age of twenty-one years, whether he does or does not come within one of these classes. ${ }^{70}$

When the Interior Department reported the census data to Congress in 1871, the Secretary said with disappointment that he was "disposed to give but little credit to the returns made by assistant marshals in regard to the denial or abridgement of suffrage." 71

Nonetheless, Congress devoted considerable attention to Section Two of the Fourteenth Amendment in debating the new reapportionment. If the census data was taken at face value, then Rhode Island and Arkansas were each at risk of losing one representative. ${ }^{72}$ Rhode Island restricted suffrage only to adult male citizens who had lived there for at least a year and owned at least $\$ 134$ of real property. ${ }^{73}$ Arkansas denied voting rights to adult male citizens who (1) had lived in the state for less than six months; (2) had been involved in a duel; (3) were insane; or (4) were barred from voting in the state where

70 Id. at 12. During the debate on Section Two, Senator Jacob Howard argued that the census takers would face "a rule which is so uncertain, so difficult of practical application, as not only greatly to increase the expenses of ascertaining the basis of representation by Congress in procuring the necessary information, but in many cases the returns must be so inaccurate and unreliable as to be next to worthless." Cong. Globe, 39th Cong., 1st Sess. 3038-39 (1866) (statement of Sen. Howard). Senator Howard's concern was well founded given the limited administrative resources available at the time.

71 Cong. Globe, 42d Cong., 2d Sess. 66 (1871). The Secretary stated that "[t]he unfavorable judgment of the Department in respect to this single class of statistics is formed, first, from the application of certain statistical tests, and second, from a consideration of the agencies employed, which are not deemed adequate to the determination of the numerous questions of difficulty and nicety which are involved." Id. No explanation was given about the "statistical tests" that were used, which makes assessing the Department's conclusion difficult. For example, was the concern that the figures overcounted or undercounted the number of disenfranchised voters?

72 See Zuckerman, supra note 8, at 112-13; see also Cong. Globe, 42d Cong., 2d Sess. 83 (1871) (statement of Rep. Garfield). This outcome depended on the overall size of the House of Representatives and the rule chosen for allocating fractions.

73 See Cong. Globe, 42d Cong., 2d Sess. 82 (1871) (statement of Rep. Cox) (quoting the Rhode Island statute). 
they resided before they moved. ${ }^{74}$ In both cases, Section Two's penalty clause would have reduced the state's fractional representative in such a way that each would lose the benefit from that fraction. ${ }^{75}$

After extended discussion, Congress concluded that Section Two should not apply to the new reapportionment. ${ }^{76}$ Part of the reason for that conclusion, in light of the Interior Secretary's dubitante statement, was that the census figures on voting were just unreliable. ${ }^{77}$ Some members of the House and the Senate argued that they should not look behind the official numbers, in part because the fault rested with Congress in not legislating to give the census takers more guidance on how to gather accurate data, but that argument did not prevail. ${ }^{78}$ Congress also might have thought that some of the voting restrictions in Rhode Island and Arkansas did not constitute a denial or an abridgment of suffrage under Section Two. But the figures reported by the census did not break out why the adult men who said they could not vote were unable to do so, which made it impossible to treat the reported data as authoritative unless all of the voting restrictions in a given state were deemed suspect. While Congress reaffirmed its commitment to Section Two by enacting a statute in 1872 to codify the penalty clause, no further thought was given to how the census should obtain the necessary information..$^{79}$ This indifference to the best method of data collection may explain why the census deleted the Section Two questions from the 1880 enumeration instructions and never asked them again. ${ }^{80}$

74 See Ninth Census Report, supra note 58, at 72.

75 The best summary of the math is in Zuckerman, supra note 8, at 112-13 n.104.

76 See Bonfield, supra note 14, at 132-33; Hurta, supra note 9, at 157-58.

77 See Cong. Globe, 42d Cong., 2d Sess. 79 (1871) (statement of Rep. Mercur) ("To arrive at an intelligent result, a blank form ought to have been prepared, containing numerous subdivisions showing (if any man said he was disfranchised) the reason or ground upon which he said his disfranchisement was based. The facts should have been reported here, and then Congress would have determined whether those facts brought the individual within this clause.").

78 See id. at 83 (statement of Rep. Garfield); id. at 670 (statement of Sen. Morrill).

79 See Act for the Apportionment of Representatives to Congress Among the Several States According to the Ninth Census, ch. 11, 17 Stat. 28 (1872). Part IV examines the relevance of this law for the Section Two objection to the current reapportionment formula. See infra text accompanying note 146 .

80 Compare History, Index of Questions: 1870, U.S. Census Bureau (July 17, 2017), https://www.census.gov/history/www/through_the_decades/index_of_questions/1870_1.html (including questions pertaining to Section Two), with History, Index of Questions: 1880, U.S. CENsus Bureau (July 17, 2017), https://www.census.gov/history/www/through_the_decades/ index_of_questions/1880_1.html (questions pertaining to Section Two removed). Part III explains that Title VIII of the Civil Rights Act of 1964 was the first serious effort since the 1870 Census to gather the kind of suffrage data contemplated by Section Two of the Fourteenth Amendment. See infra text accompanying notes 102-08. 
During the next four reapportionments, Section Two was largely ignored by Congress. The exception was in 1901, when a House resolution was introduced that would have required the Census Bureau to inform Congress how many adult male citizens there were and how many of them were denied suffrage "on account of illiteracy, on account of pauperism, on account of polygamy, or on account of property qualifications, or for any other reason." ${ }_{11}$ This resolution was triggered by a new wave of voting barriers raised in the South against African-Americans and poor whites who supported the Populist Party. ${ }^{82}$ The resolution was not adopted, but the issue was discussed at some length on the floor. ${ }^{83}$

\section{Section Two and the Reapportionment Act of 1929}

The threat of Section Two enforcement was discussed during Congress's prolonged deadlock to reapportion the House after the 1920 Census. When a House committee held hearings on the new allocation of representatives, witnesses from various civil rights groups (including the NAACP) testified that the broad disenfranchisement of African-Americans in the South must be addressed through Section Two. ${ }^{84}$ Southern members of the Committee replied that these claims were insulting and that, as one of them said, the "nigger does not participate in the white primary." 85 When a reapportionment bill moved to the House floor, one indefatigable Republican member from Massachusetts, George Tinkham, declared that if the legislation did not impose a Section Two penalty, "the Republic is destroyed and democ-

8134 Cong. REC. 556 (1901); see Zuckerman, supra note 8, at 116-20 (describing the congressional debate on this resolution and related proposals).

82 See Gerard N. Magliocca, The Tragedy of William Jennings Bryan: Constitutional Law AND the Politics of Backlash 124-26 (2011) (describing these devastating reforms). The 1904 Republican Party platform declared,

We favor such Congressional action as shall determine whether, by special discriminations the elective franchise in any State has been unconstitutionally limited, and if such be the case, we demand that representation in Congress and in the Electoral College shall be proportionally reduced, as directed by the Constitution of the United States.

Zuckerman, supra note 8, at 119.

83 See Tolson, supra note 44, at 474-78 (summarizing the debate and outcome of the resolution); see also 34 Cong. Rec. 600-03 (1901) (statement of Rep. Shattuc) (arguing for Section Two enforcement); $i d$. at 556-59 (containing some of the back-and-forth on the Section Two resolution).

84 See EAgles, supra note 5, at 35; see also W.E.B. DuBois, Reduced Representation in Congress, 21 CRISIs 149 (1921) (making a more detailed argument about Section Two).

85 EAgles, supra note 5, at 35; cf. Smith v. Allwright, 321 U.S. 649, 661-62 (1944) (declaring the all-white primary unconstitutional). 
racy annihilated." ${ }^{86}$ His plea fell on deaf ears, but for the next eight years Congressman Tinkham continued to introduce Section Two amendments to reapportionment bills. ${ }^{87}$ During the debate on the Reapportionment Act of 1929, which set up the automatic system still in use today, he proposed new Section Two language that was initially adopted by the House but was removed prior to final passage..$^{88}$

The language of Tinkham's failed proposals raises a crucial point about how Section Two should be construed in light of the Constitution's subsequent suffrage amendments. One of his proposals said that the census should count "the number of inhabitants in each state being 21 years of age and citizens of the United States, whose right to vote" in the relevant elections was denied or abridged. ${ }^{89}$ A key word is missing here-male. The Congressman recognized that the ratification of the Nineteenth Amendment should be interpreted as modifying Section Two of the Fourteenth Amendment to include women. ${ }^{90}$ Women were not part of Section Two because no state gave women a general right to vote in 1868 . Once the Constitution was revised to require female suffrage, the best reading of Section Two was that the penalty provision encompassed presumptive voters and that men and women were now in that class. ${ }^{91}$ The same reasoning applies to eighteen-year-olds since the ratification of the Twenty-Sixth Amendment in $1971 . .^{92}$

While the defeat of Congressman Tinkham's bid to enforce Section Two was unfortunate given the stranglehold of Jim Crow on the South, the constitutional flaw in the Reapportionment Act was that

86 Eagles, supra note 5, at 36-37; see also Demands Inquiry on Disfranchising, N.Y. Times, Dec. 6, 1920, at 3 (summarizing Congressman Tinkham's views).

87 See EAgles, supra note 5, at 47-48, 52, 63, 71.

88 See 71 Cong. Rec. 2364 (1929); id. at 2483; House Bars Aliens in Reapportioning: Also Votes to Exclude Negroes Disfranchised After Debate Marked by Disorder, N.Y. Times, June 5, 1929, at 11 (describing the initial passage of the Tinkham amendment); see also EAGLEs, supra note 5, at 80 (explaining that the amendment was removed in part due to concerns that the bill could not be enacted if a Section Two provision was included).

89 See 71 Cong. Rec. 2271 (1929).

90 See U.S. Const. amend. XIX, $§ 1$ ("The right of citizens of the United States to vote shall not be denied or abridged by the United States or by any State on account of sex.").

91 Likewise, Section Two did not mention voting in elections to the United States Senate because there were no popular elections for the Senate in 1868. See U.S. ConsT. amend. XVII (establishing popular election for the Senate). It would be silly to say that a state suffrage restriction in Senate elections could not be assessed as part of a Section Two penalty, though in practice states have not restricted voting rights for only one office.

92 See U.S. Const. amend. XXVI, § 1 ("The right of citizens of the United States, who are eighteen years of age or older, to vote shall not be denied or abridged by the United States or any State on account of age."). 
the statute went even further by precluding consideration of Section Two in any future automatic reapportionment. ${ }^{93}$ Congress can delegate its apportionment authority to an executive agency, but that delegation cannot be done in a manner that prohibits Section Two enforcement. Nobody appears to have noticed this defect until the 1960s, when the civil rights movement brought new attention to voting rights.

\section{The Second Reconstruction}

This Part explores the revival of interest in Section Two of the Fourteenth Amendment in the 1960s and the questions raised at that time about the validity of the reapportionment statutes. The ongoing refusal of the South to let African-Americans vote led to renewed calls in Congress for the enforcement of Section Two through the oftoverlooked Title VIII of the Civil Rights Act of 1964, which sought to gather new information about the denial or abridgement of suffrage. ${ }^{94}$ Once Section Two returned to the constitutional foreground, a few scholars realized that the reapportionment statutes were invalid and litigation was filed by the NAACP against the Secretary of Commerce challenging the Reapportionment Act. ${ }^{95}$ Before a court could reach the merits of this claim, though, the Voting Rights Act of 1965 was enacted. ${ }^{96}$ In short order, the air went out of the Section Two balloon and no decision was rendered on the constitutionality of the reapportionment process.

\section{A. Section Two and the Civil Rights Act of 1964}

When Congress took up the issue of civil rights again in 1957, legislation was proposed to consider applying Section Two. ${ }^{97}$ The initial suggestion was to create a joint congressional committee to assess if any state was violating Section Two and, if so, what penalty should

93 See supra notes 79-87 and accompanying text. Congress is, of course, free to pass new reapportionment legislation, but an unconstitutional statute is not saved just because Congress can supersede that law with a valid statute.

94 See Civil Rights Act of 1964, Pub. L. No. 88-352, § 801, 78 Stat. 241, 266. Lawyers pay far more attention to other parts of the Act (such as the provisions on employment discrimination in Title VII) than they do to Title VIII.

95 See Lampkin v. Connor, 360 F.2d 505 (D.C. Cir. 1966) (dismissing a complaint filed prior to the enactment of the Voting Rights Act).

96 See Voting Rights Act of 1965, Pub. L. 89-110, 79 Stat. 437.

97 For an exhaustive account of the negotiations that produced the Civil Rights Act of 1957, see Robert A. Caro, The Years of Lyndon Johnson: Master of the Senate 850-1000 (2002). 
be imposed..$^{98}$ This amendment was rejected by the Senate, but similar ideas were proposed in Congress over the next several years. ${ }^{99} \mathrm{~A}$ commentator sympathetic to enforcing Section Two pointed out in a 1961 article, though, that the census was superior to a committee as a means for assessing the facts on the exercise of voting rights. 100

Prodded by the call from the 1963 March on Washington for the enforcement of Section Two, Congress adopted a half-measure in Title VIII of the 1964 Civil Rights Act. ${ }^{101}$ Title VIII ordered the Secretary of Commerce to "promptly conduct a survey to compile registration and voting statistics in such geographic areas as may be recommended by the Commission on Civil Rights." 102 This survey would conduct "a count of persons of voting age by race, color, and national origin, and determination of the extent to which such persons are registered to vote, and have voted in any statewide primary or general election" for the House of Representatives since $1960 .{ }^{103}$ The same data, Title VIII added, "shall also be collected and compiled in connection with the Nineteenth[, i.e., next] Decennial Census." ${ }^{104}$ But the provision said that, unlike the census, individuals could not be compelled to answer the survey or penalized for failing to answer, which undercut the reliability of any results. ${ }^{105}$

Though Title VIII did not mention Section Two of the Fourteenth Amendment, several members of Congress expressed the hope that the voting survey would jump-start Section Two enforcement. ${ }^{106}$ For instance, Representative Charles Mathias stated that "[i]n all candor, I

98 See Zuckerman, supra note 8, at 120-21; see also 103 Cong. REc. 12,519 (1957) (statement of Sen. McNamara) (describing the proposal).

99 See Zuckerman, supra note 8, at 121

100 See id. at 123; see also id. at 131 (proposing "the employment of the United States Census Bureau for enumerating the number of disfranchised citizens in each state"). Zuckerman did not comment on the constitutionality of the reapportionment formula.

101 See supra text accompanying note 13.

102 Civil Rights Act of 1964, Pub. L. No. 88-352, § 801, 78 Stat. 241, 266.

103 Id.

104 Id.

105 Id.; see 13 U.S.C. $\$ \S 221-225$ (2012) (outlining the criminal penalties for impeding or refusing to comply with the census). It is unclear whether this limit was included for political reasons or due to a concern that imposing a national survey obligation over and above the decennial census would be unconstitutional.

106 The statistics covered by Title VIII are still collected biennially by the Commerce Department, see Voting and Registration, U.S. Census Bureau (Feb. 10, 2016), https:// www.census.gov/topics/public-sector/voting/about.html [https://perma.cc/WC6K-B9VK], though questions about voting were not included in the census form for 1970, see 1970 Questionnaire, U.S. Census Bureau, https://www.census.gov/history/pdf/1970_questionnaire.pdf [https:// perma.cc/QR4Q-LRW7]. 
am sure we all understand that the basis of [Title VIII] when it was first originated was the second section of the [Fourteenth] Amendment." ${ }^{107}$ Likewise, three Senators engaged in a colloquy explaining that one purpose of Title VIII was to give Congress the information necessary to carry Section Two into effect. ${ }^{108}$ A cautionary note was added by Representative Samuel Stratton, who stated:

Title VIII as it now stands is at least a step in the direction I have proposed that we go, that is, toward the full enforcement of the [section two] of the [fourteenth] amendment. It does not, however, require an immediate new census nor does it give the Bureau of the Census the authority ... to determine not only the extent of the abridgement of voting rights in this country but also the extent to which the representation of various States must be correspondingly reduced by reason of this voting abridgment. ${ }^{109}$

Neither Stratton nor any member of Congress, though, appears to have noticed that the reapportionment statute's prohibition on exercising this Section Two authority violated the Constitution. ${ }^{110}$

\section{B. Lampkin v. Connor}

Academics and civil rights lawyers also took a fresh look at Section Two in the 1960s, and some became convinced that the reapportionment statutes were unlawful. ${ }^{111}$ For example, a 1960 law review article took up the relevant parts of the Reapportionment Act and said that "[t]his statute is clearly unconstitutional." 112 The article reached that conclusion because the law "contemplates and perpetu-

107110 Cong. Rec. 2754 (statement of Rep. Mathias); see id. at 1643-44 (statement of Rep. Ryan) ("Title VIII provides for compilation of registration and voting statistics by race. Such statistics should serve as an index of the protection of political rights and could be used as a basis for enforcing section 2 of the 14th amendment.").

108 See id. at 6953-54. A colloquy is a formal legislative conversation on the record that attempts to establish the meaning of a bill.

109 Id. at 2768 (statement of Rep. Stratton).

110 For an excellent account of the debate on the Civil Rights Act, see Clay Risen, The Bill of the Century: The Epic Battle for the Civil Rights Act (2014).

111 A self-styled "person who is deeply devoted to civil rights" protested the absence of Section Two enforcement by refusing to answer census questions in 1960. United States v. Sharrow, 309 F.2d 77, 79 (2d Cir. 1962). He appealed his conviction for defying the census by arguing that the Census Act was unconstitutional because it did not ask Section Two questions. See id. at 80. The Second Circuit rejected that argument on the ground that there was no constitutional requirement for the census to ask questions on disenfranchisement. See id. Keep in mind that this challenge to the census was not the same as a challenge to the reapportionment process. See id.

112 Bonfield, supra note 14 , at 121-22. 
ates an apportionment based solely on population, no account being taken of those disfranchised in each state."113 Likewise, a 1965 note said, "this apportionment statute is in violation of the Constitution because it fails to take into consideration the provisions of section [two]." 114

These arguments were embraced by the NAACP Legal Defense Fund, which filed suit in 1963 in Lampkin v. Connor, ${ }^{115}$ challenging the application of the reapportionment statutes. ${ }^{116}$ The lead plaintiff was Daisy E. Lampkin, the national field secretary of the NAACP from 1935 to 1947 and the first woman to serve on the group's board of directors. ${ }^{117}$ Lampkin wrote the Commerce Secretary in early 1963 asking him to enforce Section Two of the Fourteenth Amendment. ${ }^{118}$ The Secretary replied that he could not unless Congress him gave him the power to do so. ${ }^{119}$ A complaint was filed in the District of Columbia by civil rights legend Jack Greenberg, who was part of the Brown litigation and succeeded Thurgood Marshall as the head of the NAACP's legal arm, against the Commerce Secretary and the Census Director. ${ }^{120}$ The complaint requested a declaratory judgment that these officials were obligated by statute to enforce Section Two of the Fourteenth Amendment in the reapportionment after the 1970 Census. ${ }^{121}$ If the statutes could not be construed as imposing such a duty, then the plaintiffs prayed "that the existing statutes relating to the administration of the census and the preparation of the apportionment statement be invalidated." ${ }_{122}$

113 Id. at 122.

114 Bayer, supra note 14, at 989.

115360 F.2d 505 (D.C. Cir. 1966).

116 See id. at 511 n.13 (D.C. Cir. 1966) (stating that the complaint was filed two years before the enactment of the Voting Rights Act); NAACP Challenges, supra note 15, at 5.

117 See Patricia Sullivan, Lift Every Voice 137 (2009) (providing some background on Lampkin).

118 See NAACP Challenges, supra note 15 , at 7.

119 See id.

120 See id. at 5; Lampkin v. Connor, 239 F. Supp. 757, 757 (D.D.C. 1965); Margolis, supra note 12, at 158-59 (summarizing the complaint); Theodore M. Shaw, Tribute to Jack Greenberg, 117 Colum. L. Rev. 1057, 1057, 1059 (2017) (summarizing Greenberg's career). Constance Baker Motley, another famed civil rights lawyer, was also apparently involved in Lampkin, though she does not appear as an attorney of record. See NAACP Challenges, supra note 15, at 7.

121 See Margolis, supra note 12, at 159; see also Bayer, supra note 14, at 991-92 (commenting on the litigation while on appeal). This argument was stronger than the reading, assessed in Part IV, that the reapportionment laws merely permit these officials to consider Section Two. See infra Section IV.B.

122 Lampkin v. Connor, 360 F.2d 505, 507 (D.C. Cir. 1966); see Margolis, supra note 12, at 
The District Court dismissed the complaint for want of standing but also commented on the merits. ${ }^{123}$ First, the Court (after a lengthy analysis) rejected the plaintiffs' view that the reapportionment statutes mandated or authorized Section Two enforcement. ${ }^{124}$ Second, the Court explained that the "[p]laintiffs cite no authority for" the argument that these clauses were unconstitutional if they did not require Section Two enforcement and the Court "found none." 125 This decision was a setback for voting rights, but a far more important development for that issue occurred three weeks before the District Court's opinion-Bloody Sunday in Selma, Alabama. ${ }^{126}$ The beatings of those suffrage protestors led to President Lyndon B. Johnson's speech one week later calling on Congress to pass the Voting Rights Act. ${ }^{127}$

When the D.C. Circuit affirmed the District Court's dismissal of the complaint in 1966, the suffrage zeitgeist was radically different. ${ }^{128}$ The Court framed the appeal as whether its discretion to grant a declaratory judgment should be exercised, which involved "a wider range of considerations than would be either necessary or appropriate if the only issue were one of standing." ${ }^{129}$ In Lampkin, one of those considerations was that "since this suit was first filed, Congress has moved directly and in a massive way to eliminate the injuries which this complaint seeks to get at indirectly by means of the 1970 Census and the apportionment made on the basis of it for the election of 1972." ${ }^{130}$ Thus, "considerable latitude would still seem to exist for appraisal of the effectiveness of the new Voting Rights Act before appellants turn in desperation once more to the indirect sanction they

159 ("It is further alleged that to the extent that the constitutional requiremen[t]s are not read into duties imposed upon the Bureau and the Secretary they are unconstitutional.").

123 The District Court's holding rested on the fact that the plaintiffs were individual voters who lacked the concrete interest to maintain a Section Two action. See Lampkin, 239 F. Supp. at 760-63; Bayer, supra note 14, at 984. As Part IV explains, there is no such standing obstacle when a state that suffers a harm from reapportionment brings an action. See infra text accompanying notes $152-53$.

124 See Lampkin, 239 F. Supp. at 763-66.

125 See id. at 766.

126 Lampkin was decided by the District Court on March 29, 1965. See id. at 757. Bloody Sunday was March 7, 1965. See Taylor Branch, At CanaAn's Edge: America in the King YEARs 1965-68, at 44-57 (2006) (describing those events).

127 See CARo, supra note 97, at xv-xxi (providing background on this landmark address). The prospect of new voting rights legislation may have influenced the District Court's approach toward standing in Lampkin, though there is no way to know.

128 See Lampkin v. Connor. 360 F.2d 505, 505-12 (D.C. Cir. 1966).

129 Id. at 509.

130 Id. at 510. 
believe to be imbedded in Section [Two]." ${ }^{131}$ The court concluded, "In telling appellants that events have made their complaint unsuitable for judicial disposition at this time, we think it also premature to conclude that Section [Two] of the Fourteenth Amendment does not mean what it appears to say." 132

There was wisdom and folly in Lampkin's final disposition. The wisdom was that the Voting Rights Act went a long way towards solving the underlying problem in the litigation-the denial of suffrage to African-Americans. Judicial caution was also warranted by the prospect of further legislation on that subject and on the reapportionment process. The folly was that the Voting Rights Act did not address reapportionment and left the constitutional defect that this Essay discusses in place. With the retreat of the Voting Rights Act after the Supreme Court's 2013 decision in Shelby County v. Holder, ${ }^{133}$ though, the Section Two flaw is more visible.

\section{Possible Responses to a Section Two Claim}

This Part considers some plausible counterarguments against an action claiming that the reapportionment statutes must be invalidated for violating Section Two of the Fourteenth Amendment. First, perhaps the relevant clauses can be read as giving the Commerce Department authority to consider Section Two in reapportionment. Second, maybe the question cannot be adjudicated due to standing or justiciability obstacles. Finally, even if the reapportionment statute is inconsistent with Section Two, that conflict is irrelevant in practice because there is no chance that the blunt Section Two remedy will be enforced. Each of these contentions, however, is without merit.

\section{A. Is There a Saving Construction?}

If the reapportionment statutes can somehow be read to give the Commerce Secretary the authority to consider Section Two as part of the allocation formula, then the constitutional issue identified by this Essay vanishes. The Commerce Department has steadfastly denied that the agency has any such authority, though, and when the relevant provisions are closely examined, they confirm the Department's interpretation. ${ }^{134}$

131 Id. at 511.

132 Id. at 512.

133133 S. Ct. 2612 (2013).

134 See, e.g., Hurta, supra note 9, at 170-71 n.165 (quoting a letter from the Census Director to a congressman stating that Section Two would not be used in the reapportionment calcula- 
The Reapportionment Act, as amended, says in unambiguous terms that total population is the only basis for reapportionment. Start with 13 U.S.C. $\S 141$, which states in subsection (a) that the Commerce Secretary shall take a decennial census. ${ }^{135}$ Subsection (b) then states that "[t]he tabulation of total population by States under subsection (a) of this section as required for the apportionment of Representatives in Congress among the several States shall be completed within 9 months after the census date and reported by the Secretary to the President." ${ }^{136}$ Next, 2 U.S.C. § 2a(a) provides that the President "shall transmit to the Congress a statement showing the whole number of persons in each State, excluding Indians not taxed" and "the number of Representatives to which each State would be entitled under an apportionment of the then existing number of Representatives by the method known as the method of equal proportions, no State to receive less than one Member." ${ }^{137}$ Finally, 2 U.S.C. § $2 \mathrm{a}(\mathrm{b})$ says that "[e]ach State shall be entitled" to the number of representatives in the statement transmitted by the President. ${ }^{138}$

Understanding these provisions as including a carveout for Section Two of the Fourteenth Amendment is implausible. First, the statutes refer to the "total population" and the "whole number of persons in each State" whether they are disenfranchised or not. ${ }^{139}$ The only

tions "inasmuch as the Congress has made no provision for implementing this Section"); supra text accompanying notes 118-19 (stating that the Commerce Secretary took the same position in 1963); cf. Margolis, supra note 12, at 152 ("Section 2 has been ignored in the apportionment procedure established by Congress and effectuated through the Executive Branch of the Government.").

13513 U.S.C. $\S 141(\mathrm{a})(2012)$.

136 Id. $\$ 141(\mathrm{~b})$.

1372 U.S.C $\$ 2 \mathrm{a}(\mathrm{a})$ (2012). The President has some discretion to reject the Commerce Secretary's tally, though this has never happened. See Franklin v. Massachusetts, 505 U.S. 788, 797-800 (1992) (reasoning that the tally is a recommendation that does not become final until the President gives his approval). For example, the President could order changes in the way that the census is conducted and ask that the enumeration be done again. See id. at 798. This does not mean, though, that the President can use Section Two as a basis for rejecting the tally. The statute provides no discretion on that issue and the President's Article Two powers cannot sensibly be read to address congressional apportionment, which is at the core of that branch's makeup.

138 Id. $\S 2 \mathrm{a}(\mathrm{b})$; see Bonfield, supra note 14, at 122 ("[A] state 'would be entitled' to the number of representatives due it on the basis of population alone, but it properly 'shall be entitled' only to that number minus the penalty imposed by section 2 . Therefore, a state is not always entitled to the apportionment to which it would be entitled.").

139 See Lampkin v. Connor, 239 F. Supp. 757, 764 (D.D.C. 1965); Bayer, supra note 14, at 990 (stating that 2 U.S.C. $\S 2$ a "completely ignores the express language of section 2 of the fourteenth amendment" by basing apportionment on the "whole number of persons in each State"). 
exception to the total population metric was for "Indians not taxed," the formulation that Section Two borrowed from Article One of the Constitution for Native Americans who were part of independent tribes. ${ }^{140}$ In other words, Congress was perfectly capable of reading the Constitution and including its commands in reapportionment law. Congress just failed to do so with respect to the penalty provision of Section Two.

In a recent Note that made an outstanding contribution by pointing out-for the first time in decades - the problematic relationship between Section Two of the Fourteenth Amendment and the reapportionment process, Michael Hurta argues that "total population" in 13 U.S.C. $\S 141$ (b) does not, in fact, mean "total population." ${ }^{141}$ Hurta's claim is that the phrase "as required for the apportionment of Representatives in Congress" in that subsection modifies "total population" to mean the total population relevant for purposes of Section Two. ${ }^{142}$ In essence, he says that there is an ambiguity in $\S 141$ (b) on whether the "as required" text refers to only the first sentence of Section Two, which focuses on the total number of people, or to both sentences of Section Two, which defines the penalty. ${ }^{143}$ If this is right, then the ambiguity should (under the constitutional avoidance canon) be construed in a way that would not invalidate the statute. ${ }^{144}$

The problem with Hurta's salvage attempt is that 2 U.S.C. $§ 2 \mathrm{a}(\mathrm{a})$ makes clear that total population means the "whole number of persons in each state, excluding Indians not taxed." This language comes from the first sentence in Section Two and not from the penalty provision. ${ }^{145}$ Another way to reach Hurta's conclusion would be to say that "total population" must be read in light of Congress's codification of the penalty clause of Section Two in $1872 .{ }^{146}$ A more logical conclu-

140 See U.S. Const. art. I, § 2, cl. 3.

141 See Hurta, supra note 9, at 167-68.

142 See U.S. Const. art. I, § 2, cl. 3.

143 See id.

144 See, e.g., Nat'l Fed'n of Indep. Bus. v. Sebelius, 567 U.S. 519, 562 (2012) (opinion of Roberts, C.J.).

145 See U.S. Const. amend. XIV, $\$ 2$.

146 See 2 U.S.C. $\$ 6$ (2012) ("Should any State deny or abridge the right of any of the male inhabitants thereof, being twenty-one years of age, and citizens of the United States, to vote at any election named in the amendment to the Constitution, article 14, section 2, except for participation in the rebellion or other crime, the number of Representatives apportioned to such State shall be reduced in the proportion which the number of such male citizens shall have to the whole number of male citizens twenty-one years of age in such State."). The District Court in Lampkin said that " $[\mathrm{t}]$ his section is merely declaratory of $\S 2$ of the Fourteenth Amendment. It does not implement that constitutional provision." Lampkin v. Connor, 239 F. Supp. 757, 766 n.13 (D.D.C. 1965). 
sion is that the Reapportionment Act implicitly repealed that codification by establishing a process that did not mention Section Two. Even assuming that no implicit repeal occurred, the codification is now unconstitutional because of the statute's use of men over the age of twenty-one (rather than men and women over the age of eighteen) as the relevant baseline for presumptive voters.

\section{B. Justiciability and Standing}

Though the reapportionment statutes cannot plausibly be read as permitting the Commerce Department to consider Section Two, one could argue that the courts cannot reach the resulting constitutional violation. An individual voter or group of voters, for instance, probably lacks standing to bring an action that is tantamount to an abstract claim that a portion of the Constitution is not being followed. ${ }^{147}$ If, however, a state brings an action seeking injunctive relief, then the claim would likely be justiciable.

In United States Department of Commerce v. Montana,${ }^{148}$ the Supreme Court unanimously held that a state that lost a representative after a census could raise a constitutional challenge to the reapportionment statutes. ${ }^{149}$ Montana lost a House member after the 1990 Census and argued that the method of equal proportions violated the Equal Protection Clause. ${ }^{150}$ The state explained that under at least two alternative approaches to allocating fractional representatives Mon-

147 There were a few cases brought by individuals that unsuccessfully sought to raise a Section Two claim in a tangential way. For instance, in 1948, a conviction for contempt of Congress was challenged in part on the ground that Section Two of the Fourteenth Amendment prohibited a member of the relevant House committee from being seated. See Dennis v. United States, 171 F.2d 986, 992-93 (D.C. Cir. 1948). The Court rejected this argument because "[t]he validity of the Apportionment Act of 1941 cannot be attacked in a collateral proceeding." Id. at 993. Likewise, a man who was barred from running as a congressional candidate in Virginia attacked that decision by claiming in part that the state's poll tax violated Section Two. See Saunders v. Wilkins, 152 F.2d 235, 237 (4th Cir. 1945). The Court rejected that claim in part by pointing out that under Supreme Court precedent at the time, a poll tax was constitutional. See id.

148503 U.S. 442 (1992).

149 See id. at $456-59$.

150 See id. at 445-46. The argument, in a nutshell, was that the method of equal proportions deviates from the one-person, one-vote principle as between states. One way of explaining this is that the constitutional requirement that each state receive at least one representative means that the smallest states are overrepresented. In other words, a state that should get three-quarters of a House member under a population calculation actually gets one. This sort of problem could be corrected if the overall size of the House of Representatives were increased to the point that the ratio of people to representative was tied to the population of the smallest state, but the Court did not say that this sliding scale was constitutionally required. For a fine review of this question, see Ladewig, supra note 21, at 1143-50. 
tana would not have lost a member, though under two other standards that Congress could have chosen the state would have still lost one. ${ }^{151}$ Before rejecting the state's claim on the merits, the Court addressed and rejected the Commerce Department's position that the case presented a political question. ${ }^{152}$ The Court explained that "the interpretation of the apportionment provisions of the Constitution is well within the competence of the Judiciary."153

If a challenge to the reapportionment statutes grounded on Section One of the Fourteenth Amendment does not involve a political question, then there is every reason to believe that a challenge based on Section Two also does not present one. This is especially true given that the Section Two claim explored in this Essay does not address the substance of the penalty clause (in other words, what constitutes a denial or an abridgment of suffrage), which could well raise a political question. The only issue for the courts to resolve here is whether Congress is prohibited from imposing a total ban on Section Two enforcement during reapportionment. ${ }^{154}$ Nothing about that narrow legal question raises a problem unsuited for judicial resolution.

While Montana did not discuss standing, the Court's decision to reach the merits in that case is best read to mean that a state with a plausible claim that a valid reapportionment could have given that state an extra representative has standing to bring a constitutional challenge to the process. Many states are in that boat after each census because their fractional representatives fall just shy of what is required to obtain an additional House member and thus can plausibly contend that a reapportionment where Section Two review was a live option might have altered the results. ${ }^{155}$ One might object that no state can show that applying any Section Two standard would change the reapportionment results, but that is true in large part because Congress has not articulated a Section Two standard or given the Commerce Department a reason to gather the suffrage data that states would need to prove their case. To convert Congress's longstanding violation of Section Two of the Fourteenth Amendment into

151 See Montana, 503 U.S. at 455-56.

152 See id. at 459.

153 Id. at 458 .

154 There is a possibility that the next reapportionment could be delayed for an election cycle if Congress fails to act promptly in the wake of such a judicial decree. This is why Congress should act now to amend the relevant statutory provisions.

155 States that barely qualify for an extra House member would be in the weakest position to assert standing, along with the smallest states (for example, Wyoming) that are entitled to far less than one representative using a total population count. 
a shield against standing to attack that violation would be, essentially, a circular argument. ${ }^{156}$

\section{Is This Pointless Formalism?}

A final reason for hesitating to accept the argument that the reapportionment statutes violate Section Two is a pragmatic one. The logic might go something like this: Section Two will never be enforced because the political costs of imposing a representation penalty are so high. Given that reality, requiring Congress to provide the Commerce Department or some other institution with discretion to enforce Section Two would disrupt the well-oiled apportionment process for no purpose. ${ }^{157}$ Assuming for the sake of discussion that this sort of objection can overcome the unambiguous language of Section Two, the argument still comes up short because forcing Congress to obey the constitutional text in this instance is not an empty or a symbolic gesture even if a Section Two penalty is never imposed.

The principal benefit of an injunction against implementation of the current process is that Congress would be forced to legislate for any new reapportionment to occur. ${ }^{158}$ While the necessary statutory amendment could be a bare-bones delegation of Section Two discretion, Congress would have the opportunity to undertake a more searching inquiry into voting rights and examine the meaning of Section Two. Shining a spotlight on suffrage regulation is worthwhile even if a broad law is not enacted. Likewise, granting discretion to the Commerce Department (if that is what Congress decides to do) would give the executive branch the chance to think through what substantive standards should apply for Section Two. ${ }^{159}$

The other reason to cheer the extension of Section Two discretion is that the Commerce Department would be more inclined to ask questions about voting rights as part of the census. While the Census

156 Though not necessary for standing, by 2021 a state may be able to demonstrate that a broad reading of Section Two would change the reapportionment results, though that would require studies by independent experts focused on that specific question.

157 In theory, Congress could vest Section Two discretion in the legislative branch, such as a House committee or the General Accountability Office. In practice, though, separating the administration of the census from the constitutional analysis required by Section Two would be cumbersome, and it is hard to imagine a legislative organ conducting the census effectively.

158 Granted, a major virtue of the automatic reapportionment system is that Congress does not need to legislate every decade. Asking Congress to do this once to fix the constitutional defect in the current system, though, is not asking too much.

159 Congress could require the Executive Branch to develop these standards, but if that is not done there will eventually be a Commerce Secretary who will exercise his or her Section Two discretion. 
Bureau is free to ask those sorts of questions now, one can understand the Bureau's reluctance to do that given the complexity of gathering that data and its irrelevance under current law. Once there is the possibility that the information could change congressional representation, however, the incentive to inquire into suffrage would be greater. And questions about voting on the census form would highlight the importance of that issue for every citizen, give researchers and officials a better grasp of the problem of disenfranchisement, and give many states pause if they consider new voting regulations. ${ }^{160}$ On the last point, if Section Two regulations are adopted, they will create a de facto national standard for voting that the states will ignore at their peril.

In sum, the inconsistency between Section Two of the Fourteenth Amendment and the reapportionment statutes cannot be resolved on a formal or a pragmatic basis. If a state that loses out on an extra representative following the next census raises a Section Two claim in litigation, the federal courts can and should declare the statutes unconstitutional in the absence of an act of Congress that fixes the problem.

\section{CONCLUSION}

The understandable attention given to the partisan drawing of some congressional districts should not obscure the fact that the reapportionment process that precedes redistricting is unconstitutional. ${ }^{161}$ Section Two of the Fourteenth Amendment provides that the apportionment of representatives among the states must be done based on total population unless a state disenfranchises a sufficient number of people who are presumptively eligible voters. The reapportionment statutes provide that apportionment must be done based only on total population. By erasing Section Two's penalty clause, these statutes are unlawful. There is still time for Congress to correct this flaw before the next census. If that does not occur, then the federal courts should declare the next reapportionment null and void in an appropriate case.

160 The only states that could not face a Section Two penalty are the smallest ones entitled to only one representative, as they cannot receive zero no matter how many of their citizens are barred from voting.

161 See, e.g., Gill v. Whitford, 138 S. Ct. 1916 (2018). 